\title{
The Relationship between Learning Style, Test Anxiety and Academic Achievement
}

\author{
Kubilay Yazıcı \\ Faculty of Education, Omer Halisdemir University, Central Campus, Turkey
}

Copyright $\bigcirc 2017$ by authors, all rights reserved. Authors agree that this article remains permanently open access under the terms of the Creative Commons Attribution License 4.0 International License

\begin{abstract}
This study aimed to investigate the relationship between social studies pre-service teachers' (SSPTs) learning style, test anxiety and academic achievement. A total of 315 SSPTs participated in the study. Data were collected using Turkish versions of Grasha-Reichmann learning style scale (GRLSS) and test anxiety scale (TAS) by Spielberger. According to the findings, SSPTs' academic achievements had negative and low-level relationship with the TAS' worry sub-dimension while they had no significant relationship with the emotionality sub-dimension. No statistically significant relationship was observed between test anxiety and independent, participant and avoidant learning styles, which are among GRLSS subdimensions. The findings revealed that competitive and cooperative learning styles had positive, low-level and significant relationship with the TAS' emotionality subdimension, and the same relationship was observed between the competitive learning style and the worry sub-dimension. The relationship of gender and class level with learning styles and test anxiety was also investigated in this study.
\end{abstract}

Keywords Academic Achievement, Learning Style, Test Anxiety, Social Studies, Pre-service Teacher

\section{Introduction}

Learning, which is said to be a process, consists of various dimensions including planning, application, assessment and evaluation [58]. In parallel with the developments in instruction today, it is stated that the relation between the teaching, learning and evaluation processes has become more productive [67]. In academic studies conducted in this field, the variables that affect student success are tested as "students are the basic focus point of instructional systems" [82, p.6].

Although there are differences in the meaning attributed to the term success [55, p.571], improving education and enabling students to achieve their learning objectives or to become successful, have long become among the aims of educators and politicians [37, p.687]. In this context, with reference to the idea that the reasons for students' success or failure should be thought of as being multidimensional and multivariable [85, p.12], studies aiming to determine the factors that affect students' success have an important place in educational research.

The effects of many individual and environmental factors on student success including student's age [65], attention [57], motivation [63], past [50], socio-economical state [12, 60], teacher's behaviors [26], teaching methods used by the teacher [42], class size [2,5,66], and peers [41] have been investigated by researchers in the education field.

It is frequently mentioned in related literature that individuals have different learning styles, which play an important role in the learning process $[13,14,68]$ and that test anxiety affects student success negatively $[8,15,76]$ in exams, which are the essential tools in testing the effectiveness of schools and in determining whether students succeed academically [87]. With reference to these claims, the purpose of this study is to examine the effect of students' learning styles and their test anxieties on each other and on the students' academic successes.

Carrying out the application part of the study together with social studies pre-service teachers (SSPTs) is of particular importance. It is because social studies, which is not a science itself but a field of study consisting of social and human sciences designed to improve students' citizenship efficiencies, includes having to learn and succeed in various sciences, from history to psychology, mathematics or natural sciences [70]. This makes it necessary for future SSPTs to take classes on different sciences during their undergraduate education.

\subsection{Theoretical Background}

\subsubsection{Test Anxiety}

Anxiety is generally defined as the state of concern and fear $[4,64]$ occurring as a result of stress that people often have to contend with in every aspect of their lives and at every age $[61,86]$ and that causes cognitive, affective, behavioral and physical reactions [80, p. 931]. Test anxiety 
is stated as an emotional reaction or state of stress that occurs before exams and lasts during the exam period $[8$, 48].

The terms fear of test and test anxiety that are used interchangeably in literature, although they have different indicators, should be given attention [3]. Fear represents the reaction to a specific observable danger while anxiety is an aimless state of concern [6]. It is stated that fear of test motivates a person as long as it is within reason [3] while test anxiety is said to affect students negatively, cognitively, sensually and behaviorally $[7,15,18,76]$. As a result of such negative effects of test anxiety on students, studies aimed at determining and minimizing the effects of certain factors on students' test anxiety levels have gained momentum, and suggestions for minimizing students' levels of test anxiety have been made frequently in literature [79]. Although various comments have been made about the origins of test anxiety, it is stated that many factors including socioeconomic and demographic variables, educational systems and cultural values of education [24], certain emotional states, students' past experiences and beliefs [64] affect the development of test anxiety.

\subsubsection{Learning Style}

Following Dunn and Dunn's [31] claim that learning is individual and occurs differently at every single age and intellectual capacity, the idea that students have different preferences in the periods of receiving and processing knowledge [40], or their learning process works differently as they have different learning styles, is accepted among educators $[40,49,62,69,75]$.

While there is not one single definition of learning style that is commonly accepted by everyone related to the issue [27], various definitions in which individual learning and student preferences are emphasized [30,53] and that are associated with personality $[47,49]$ exist in literature. In brief, "Learning style is the usual way one prefers in the process of acquiring, proceeding and storing new information." [17, p. 290] and "... consists of distinctive behaviors which serve as indicators of how a person learns from and adapts to his environment. It also gives clues as to how a person's mind operates" [44, p. 234].

The characteristics of learning styles that enable individualized instruction [33] serve to understand how students receive information in different ways [21] and help learning process to occur systematically. With reference to the fact that even experienced teachers cannot determine all their students' learning styles through observation [32, p. 79], various learning style models/inventories have been developed. When related literature is examined, it is seen that more than 70 scales based on different classifications [45,51] exist including many well-known scales such as "Dunn and Dunn- Learning Styles Inventory", "Felder and Silverman- Index of Learning Styles", "Grasha-RiechmannStudent Learning Style Scales", "Gregorc Mind Styles Delineator", "Honey and Mumford- Learning Styles
Questionnaire", "Kolb- Learning Style Inventory", "MyersBriggs Type Indicator" and "Vermunt- Inventory of Learning Styles".

\subsection{Present Study}

The main purpose of this study is to determine whether there is a relation between SSPTs' learning styles, levels of test anxiety and academic successes. Besides this purpose, the effects of SSPTs' gender and class level on their learning styles and test anxieties are also tested. The research questions developed within the study are the following:

Research Question 1: Is there a relation between SSPTs' test anxieties and academic successes?

Research Question 2: Is there a relation between SSPTs' learning styles and academic successes?

Research Question 3: Is there a relation between SSPTs' learning styles and test anxieties?

Research Question 4: Does gender affect SSPTs' learning styles?

Research Question 5: Does gender affect SSPTs' test anxieties?

Research Question 6: Does class level affect SSPTs' learning styles?

Research Question 7: Does class level affect SSPTs' test anxieties?

\section{Method}

This study was designed on the basis of Relational Screening Model, "a research model that aims to identify the existence and/or level of covariance between two or more variables" [54, p.81].

\subsection{Participants}

The study group consists of 315 SSPTs ([1] class: 42 females +40 males: 82 , [2] class: 35 females +41 males: 76, [3] class: 46 females +40 males: 86, [4] class: 34 females +37 males: 71 ) out of 399 SSPTs (186 females, 213 males) studying in the Department of Social Studies Education, Primary Education Department, Faculty of Education, Ömer Halisdemir University. The participants were chosen on a voluntary basis and 79 SSPTs who did not volunteer or could not be contacted anymore at the time the screening was conducted were not included in the study group. Also, the responses of five SSPTs who did not fill out the personal information part of the form or ranked more than one answer for some items were no longer included in the analysis.

\subsection{Data-gathering Instruments}

The Grasha - Riechmann Learning Style Scale (GRLSS), 
the Test Anxiety Scale (TAS) and the Personal Information Form (PIF) were used as assessment tools in the study.

\subsubsection{Test Anxiety Scale}

TAS, the original of which was developed by Spielberger in 1980 and consisted of worry and emotionality subdimensions, is a Likert-type scale with 20 items. The scale was adapted to Turkish by Albayrak Kaymak [1] and Öner [72]. Internal consistency, which was found to be between .92 and .96 in the statistical process conducted by Spielberger was calculated to be between .82 and .92 in the Turkish form of the scale. Item load value in the original form was between $.61-.69$ while it was between .46 and .53 in the Turkish form $[1, p .62]$. The factor analysis of the Turkish version of the scale showed that 12 items comprised the emotionality dimension and eight items formed the worry dimension as in the original form. Cronbach's Alpha value for the whole scale was calculated as 0.87 [72,73]. However, Cronbach's Alpha value in this study was found to be .92 .

The highest point to reach in this scale is 80 while the lowest is 20 [1, p.56]. The point taken from the scale also indicates how high the student's anxiety level is [73]. Participants responded on a 4-point scale ranging from $1=$ Never, $2=$ Sometimes, $3=$ Often, to $4=$ Always. The main reasons why TAS was used in this study are the following:

- to show statistically that the scale developed by Spielberger (1980) still preserves its actuality and reliability in Turkey and that it may be considered as a cross-cultural scale considering the fact that it was used in more than 20 countries including Israel, Norway, India, Pakistan, Italy, China, Hungary and Greece $[10,83]$ and

- to state that the scale is appropriate to a wide range of age groups $[1$, p. 56] and that it can be applied for testing university students' test anxiety [18].

\subsubsection{Learning Style Scale}

The Turkish version of the GRLSS [78], by Sarıtas and Süral [81], was used in this study. It is a five-point Likert scale with 60 items and six dimensions, namely Independent, Dependent, Collaborative, Competitive, Participant and Avoidant. The Cronbach's alpha value during the adaptation of the scale into Turkish, was measured as .80 for the whole scale [81]. Cronbach Alpha value in this study was found to be .92. Participants responded on a 5-point scale ranging from $1=$ completely disagree, to $5=$ fully agree.

Some characteristic features revealed by students in the dimensions existing in the scale, stated by Riechmann and Grasha [78, p.221-222] were the following:

"1. Independent. This response style is characteristic of the student who likes to think for himself...

2. Dependent. This style is characteristic of the student who shows little intellectual curiosity and who learns only what is required...
3. Collaborative. This style is typical of the student who feels he can learn the most by sharing his ideas and talents...

4. Competitive. This response style is exhibited by the student who learns the material in order to perform better than others in the class...

5. Participant. This style is characteristic of the student who wants to learn the course content and likes to go to class.

6. Avoidant. This response style is typical of a student who is not interested in learning the course content in the traditional classroom..."

The main reasons for using the Turkish version of GRLSS [81] in this study are the following:

- It is stated that the learning style scale developed by Grasha and Riechmann contains all the psychological-type theories, making it strong and ready to be used in determining the individual differences that have impacts on learning [43, p.119-120].

- Due to the dimensions and items included in the scale, GRLSS is an appropriate scale to determine the learning styles of university students [81] and it has a structure focusing on the attitudes of students to teachers, other students, classroom activities and learning style in general $[16,27,28]$.

\subsubsection{Personal Information Form}

The gender, class level and general academic averages of the students studying in the Department of Social Studies Education were included in the PIF. Having regard to the fact that general academic average is the most correct and reliable tool to determine the success level of students at graduate level [77, p. 354], the SSPT success levels in this study were assessed based on general academic achievement scores. Because the general academic achievement averages in the university where the study took place are graded using a four-point grading system, students were asked to rank their general academic averages as " 0 0.5 ", "0.51 - 1", "1.01 - 1.5", "1.51 - 2", "2.01 - 2.50", " $2.51-3.00$ ", " $3.01-3.50$ " and "3.51-4.00".

\subsection{Procedure}

Within the application process of this study, the steps taken in sequence were the following:

- Permission to use the Turkish versions of GRLSS and TAS were sought and received from the academicians who developed them.

- $\quad$ SSPTs were informed about the purpose of the study and about the process to be carried out in detail, and that inclusion to the study was voluntary.

- The PIF, GRLSS and TAS were distributed to the students within the same week and they were made to be applied within one class hour (45 minutes). 
- The responses of the SSPTs to the PIF and to the scales were statistically analyzed.

- $\quad$ Finally, the findings were discussed by supporting them with literature.

\subsection{Data Analysis}

Bivariate correlation, independent samples t-test and oneway ANOVA tests were used for the statistical analysis of the data; tables were created and descriptive statistics were used to create graphics. The correlation coefficients for “0.00-0.30", 0.31-0.70" and "0.71-1.00" were measured as low relation, moderate relation and high relation, respectively $[11, \mathrm{p} .32]$.

\section{Results}

\subsection{The Relationship between "Test Anxiety" and "Academic Achievement"}

Table 1. The relationship of academic achievement with the whole test anxiety scale and its sub-dimensions.

\begin{tabular}{|c|c|c|c|c|c|}
\hline & & \multirow{2}{*}{$\begin{array}{c}\text { Academic } \\
\text { Achievement }\end{array}$} & \multicolumn{2}{|c|}{$\begin{array}{c}\text { Dimensions of Test } \\
\text { Anxiety }\end{array}$} & \multirow{2}{*}{$\begin{array}{l}\text { Total } \\
\text { Scale }\end{array}$} \\
\hline & & & Worry & Emotionality & \\
\hline \multirow{3}{*}{$\begin{array}{c}\text { Academic } \\
\text { Achievement }\end{array}$} & $\mathrm{r}$ & 1 & $-.183 * *$ & -.057 & -.111 \\
\hline & $\mathrm{p}$ & & .001 & .312 & 0.50 \\
\hline & $\mathrm{n}$ & 315 & 315 & 315 & 315 \\
\hline
\end{tabular}

$* * \mathrm{p}<.01$.

When the SSPT levels of academic achievement and test anxiety were examined, no significant relationship was found between academic achievement levels and TAS as a whole or only with the emotionality sub-dimension. However, it was seen that there was a significant, negative and low-level relationship between the worry subdimension and the academic achievement levels (Table 1).

\subsection{The Relationship between "Learning Style" and "Academic Achievement"}

When the relationship was examined between SSPT's academic achievement levels and learning styles, which constitute the GRLSS, the following findings were observed:

Academic achievement levels have significant, positive and low-level relationship with independent, cooperative and dependent learning styles. There is positive, moderatelevel and significant relationship between participant learning style and academic achievement levels. A negative, low-level and significant relationship exists between avoidant learning style and academic achievement levels (Table 2).

\subsection{The Relationship between "Learning Style" and "Test Anxiety"}

The analysis of the sub-dimensions of GRLSS and TAS showed that there was a positive, low-level and significant relationship between the dependent, competitive and participant learning styles and the emotionality subdimension. Such a relationship was also found between the competitive learning style and the worry sub-dimension. No significant relationship was found between the independent, avoidant and collaborative sub-dimensions in GRLSS and the worry and emotionality sub-dimensions in TAS (Table 3).

Table 2. The relationship between academic achievement and learning styles.

\begin{tabular}{|c|c|c|c|c|c|c|c|c|}
\hline & \multirow{2}{*}{\multicolumn{2}{|c|}{$\begin{array}{c}\text { Academic } \\
\text { Achievement }\end{array}$}} & \multicolumn{6}{|c|}{ Dimensions of GRLSS } \\
\hline & & & Independent & Avoidant & Collaborative & Dependent & Competitive & Participant \\
\hline \multirow{3}{*}{$\begin{array}{c}\text { Academic } \\
\text { Achievement }\end{array}$} & $\mathrm{r}$ & 1 &, $187 * *$ &,$- 302 * *$ &, $138 *$ &, $179 * *$ & ,108 &, $310 * *$ \\
\hline & $\mathrm{p}$ & &, 001 &, 000 &, 015 &, 001 &, 055 &, 000 \\
\hline & $\mathrm{n}$ & 315 & 315 & 315 & 315 & 315 & 315 & 315 \\
\hline
\end{tabular}

$* \mathrm{p}<.05 . * * \mathrm{p}<.01$. 
Table 3. The relationship of the whole TAS and its sub-dimensions with GRLSS sub-dimensions.

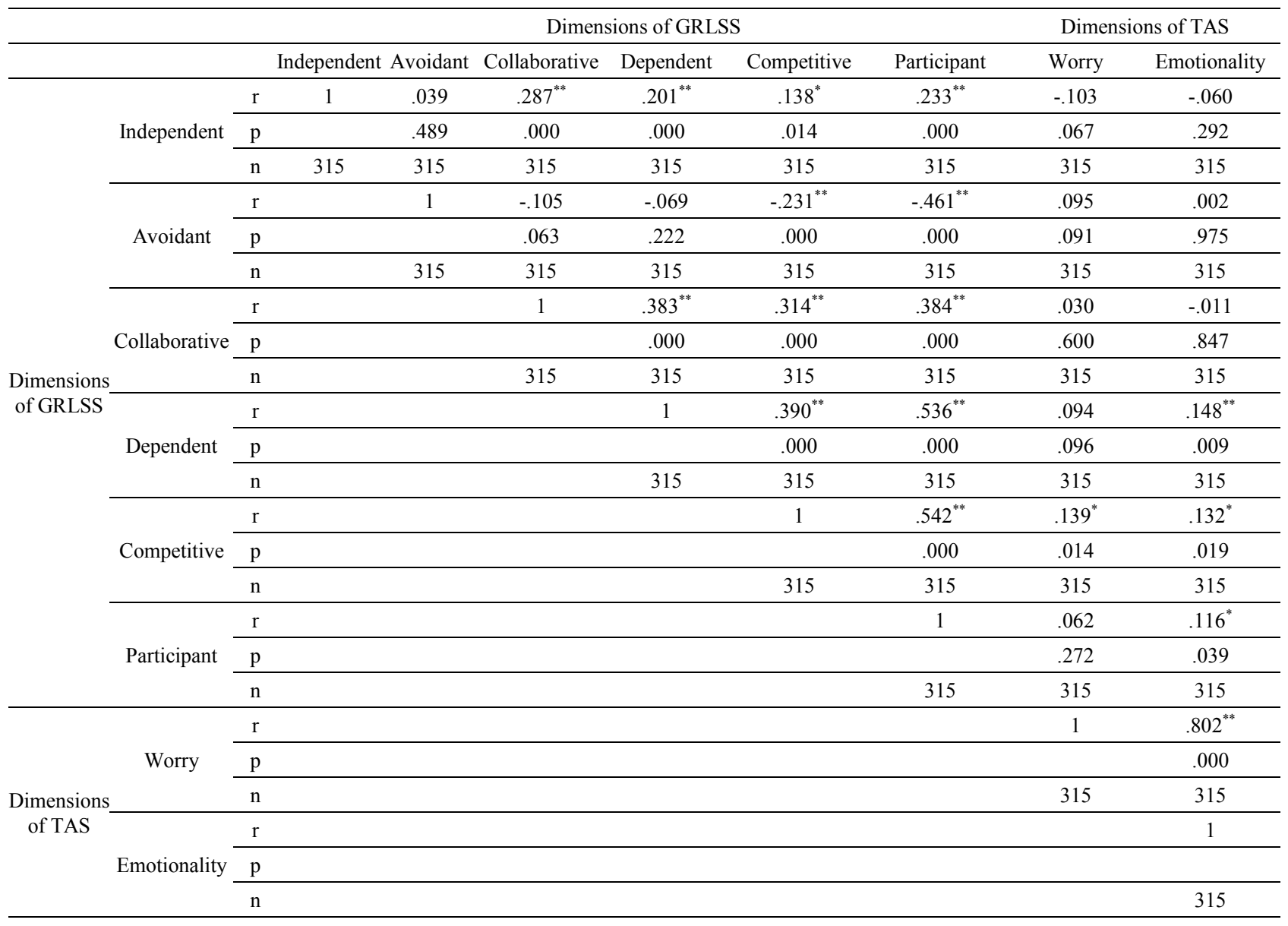

$* \mathrm{p}<.05 . * * \mathrm{p}<.01$.

\subsection{The Relationship between "Gender" and "Learning Style"}

When the relationship between gender and learning style was examined, it was seen that the independent learning style $(\mathrm{t}(313)=1.198, \mathrm{p}>0.05)$, cooperative learning style $(\mathrm{t}(313)=.218, \mathrm{p}>0.05)$ and competitive learning style $(\mathrm{t}(313)=1.263$, $\mathrm{p}>0.05)$ did not differ according to gender. However, the avoidant learning style $(\mathrm{t}(313)=4.491, \mathrm{p}<0.05)$, dependent learning style $(\mathrm{t}(313)=4.532, \mathrm{p}<0.05)$ and cooperative learning style $(\mathrm{t}(313)=4,101, \mathrm{p}<0,05)$ differed according to gender (Table 4).

Table 4. The distribution of GRLSS according to gender.

\begin{tabular}{|c|c|c|c|c|c|c|}
\hline Dimensions of GRLSS & Gender & $\mathrm{n}$ & $\bar{x}$ & $\mathrm{~s}$ & $\mathrm{t}$ & $\mathrm{p}$ \\
\hline \multirow{2}{*}{ Independent } & Female & 157 & 38.55 & 4.02 & \multirow{2}{*}{1.198} & \multirow{2}{*}{.232} \\
\hline & Male & 158 & 39.12 & 4.36 & & \\
\hline \multirow{2}{*}{ Avoidant } & Female & 157 & 27.36 & 5.30 & \multirow{2}{*}{4.491} & \multirow{2}{*}{$.000 * *$} \\
\hline & Male & 158 & 30.33 & 6.37 & & \\
\hline \multirow{2}{*}{ Collaborative } & Female & 157 & 37.97 & 5.20 & \multirow{2}{*}{.218} & \multirow{2}{*}{.828} \\
\hline & Male & 158 & 38.11 & 5.65 & & \\
\hline \multirow{2}{*}{ Dependent } & Female & 157 & 39.27 & 3.90 & \multirow{2}{*}{4.532} & \multirow{2}{*}{$.000^{* *}$} \\
\hline & Male & 158 & 37.13 & 4.46 & & \\
\hline \multirow{2}{*}{ Competitive } & Female & 157 & 34.47 & 6.31 & \multirow{2}{*}{1.263} & \multirow{2}{*}{.208} \\
\hline & Male & 158 & 33.43 & 8.20 & & \\
\hline \multirow{2}{*}{ Participant } & Female & 157 & 38.17 & 4.88 & \multirow{2}{*}{4.101} & \multirow{2}{*}{$.000^{* *}$} \\
\hline & Male & 158 & 35.66 & 5.89 & & \\
\hline
\end{tabular}

$* * \mathrm{p}<.01$. 
The averages obtained after the analysis showed that the difference observed in avoidant learning style was in favor of males while that in dependent and cooperative learning styles was in favor of females (Figure 1).

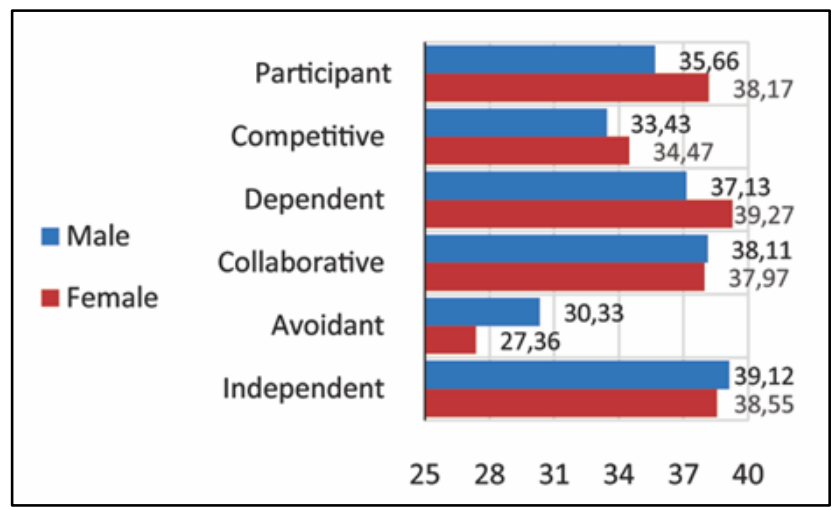

Figure 1. The distribution of learning styles according to gender

\subsection{The Relationship between "Gender" and "Test Anxiety"}

In terms of the relationship between the gender of SSPTs and their test anxieties, it was seen that the worry subdimension of TAS $(\mathrm{t}(313)=1.939, \mathrm{p}>0.05)$ did not differ according to gender whereas the emotionality subdimension $(\mathrm{t}(313)=4.394, \mathrm{p}<0.05)$ and the whole scale $(\mathrm{t}(313)=3.611, \mathrm{p}<0.05)$ differed according to gender (Table $5)$.

When the averages were examined, it was seen that the test anxieties of female students were higher (Figure 2).

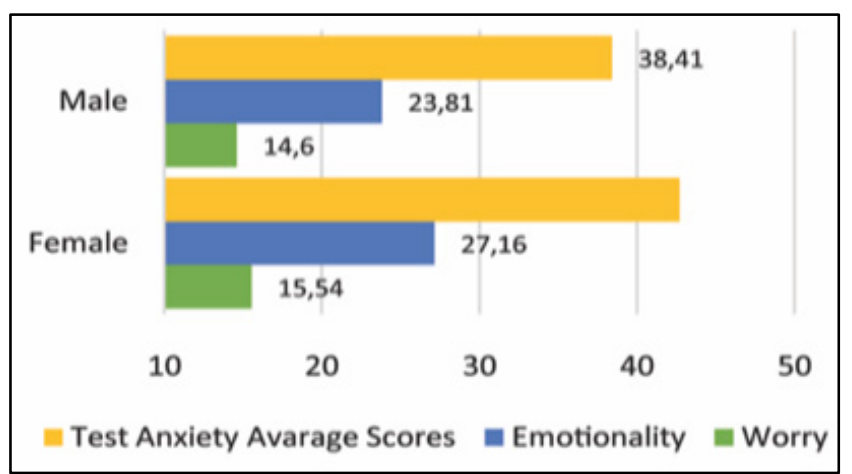

Figure 2. The distribution of test anxiety according to gender

\subsection{The Relationship between "Learning Style" and "Class Level"}

The results of the analysis showed that there was no statistically significant difference between SSPTs' learning styles and their class levels (Table 6).

Table 5. The distribution of the whole test anxiety scale and its sub-dimensions according to gender.

\begin{tabular}{|c|c|c|c|c|c|c|c|}
\hline & & Gender & $\mathrm{n}$ & $\bar{x}$ & $\mathrm{~s}$ & $\mathrm{t}$ & $\mathrm{p}^{*}$ \\
\hline \multirow{6}{*}{$\begin{array}{l}\text { Dimensions of } \\
\text { Test Anxiety }\end{array}$} & \multirow{2}{*}{ Worry } & Female & 157 & 15.54 & 4.18 & \multirow{2}{*}{1.939} & \multirow{2}{*}{.053} \\
\hline & & Male & 158 & 14.60 & 4.42 & & \\
\hline & \multirow{2}{*}{ Emotionality } & Female & 157 & 27.16 & 6.61 & \multirow{2}{*}{4.394} & \multirow{2}{*}{$.000 * *$} \\
\hline & & Male & 158 & 23.81 & 6.91 & & \\
\hline & \multirow{2}{*}{ TAS Total Scale } & Female & 157 & 42.70 & 10.09 & 3.611 & $.000 * *$ \\
\hline & & Male & 158 & 38.41 & 10.96 & & \\
\hline
\end{tabular}

$* * \mathrm{p}<.01$.

Table 6. The distribution of learning styles according to class level.

\begin{tabular}{|c|c|c|c|c|c|c|}
\hline Dimensions of GRLSS & & Sum of Squares & df & Mean Square & $\mathrm{F}$ & $\mathrm{p}$ \\
\hline \multirow{3}{*}{ Independent } & Between Groups & 62.623 & 3 & 20.874 & \multirow{3}{*}{1.188} & \multirow{3}{*}{.315} \\
\hline & Within Groups & 5466.120 & 311 & 17.576 & & \\
\hline & Total & 5528.743 & 314 & & & \\
\hline \multirow{3}{*}{ Avoidant } & Between Groups & 168.950 & 3 & 56.317 & \multirow{3}{*}{1.554} & \multirow{3}{*}{.201} \\
\hline & Within Groups & 11273.037 & 311 & 36.248 & & \\
\hline & Total & 11441.987 & 314 & & & \\
\hline \multirow{3}{*}{ Collaborative } & Between Groups & 79.374 & 3 & 26.458 & \multirow{3}{*}{.900} & \multirow{3}{*}{.442} \\
\hline & Within Groups & 9147.090 & 311 & 29.412 & & \\
\hline & Total & 9226.463 & 314 & & & \\
\hline \multirow{3}{*}{ Dependent } & Between Groups & 14.374 & 3 & 4.791 & \multirow{3}{*}{.255} & \multirow{3}{*}{.858} \\
\hline & Within Groups & 5848.026 & 311 & 18.804 & & \\
\hline & Total & 5862.400 & 314 & & & \\
\hline \multirow{3}{*}{ Competitive } & Between Groups & 264.577 & 3 & 88.192 & \multirow{3}{*}{1.655} & \multirow{3}{*}{.177} \\
\hline & Within Groups & 16576.611 & 311 & 53.301 & & \\
\hline & Total & 16841.187 & 314 & & & \\
\hline \multirow{3}{*}{ Participant } & Between Groups & 123.078 & 3 & 41.026 & \multirow{3}{*}{1.338} & \multirow{3}{*}{.262} \\
\hline & Within Groups & 9538.433 & 311 & 30.670 & & \\
\hline & Total & 9661.511 & 314 & & & \\
\hline
\end{tabular}


Table 7. The distribution of the whole TAS and its sub-dimensions according to class level.

\begin{tabular}{|c|c|c|c|c|c|c|c|}
\hline & & & Sum of Squares & df & Mean Square & $\mathrm{F}$ & $\mathrm{p}$ \\
\hline \multirow{6}{*}{$\begin{array}{c}\text { Dimensions } \\
\text { of Test } \\
\text { Anxiety }\end{array}$} & \multirow{3}{*}{ Worry } & Between Groups & 121.634 & 3 & 40.545 & \multirow{3}{*}{2.196} & \multirow{3}{*}{.089} \\
\hline & & Within Groups & 5742.829 & 311 & 18.466 & & \\
\hline & & Total & 5864.463 & 314 & & & \\
\hline & \multirow{3}{*}{ Emotionality } & Between Groups & 180.216 & 3 & 60.072 & \multirow{3}{*}{1.243} & \multirow{3}{*}{.294} \\
\hline & & Within Groups & 15024.400 & 311 & 48.310 & & \\
\hline & & Total & 15204.616 & 314 & & & \\
\hline & \multirow{3}{*}{ TAS Total } & Between Groups & 560.128 & 3 & 186.709 & \multirow{3}{*}{1.628} & \multirow{3}{*}{.183} \\
\hline & & Within Groups & 35661.859 & 311 & 114.668 & & \\
\hline & & Total & 36221.987 & 314 & & & \\
\hline
\end{tabular}

\subsection{The Relationship between "Class Level" and "Test Anxiety"}

With respect to this analysis, there was no statistically significant difference between SSPT's class levels and the whole TAS and its sub-dimensions (Table 7).

\section{Discussion}

The variables in SSPTs' PIF (gender, class level and academic achievement score) and SSPTs' replies to GRLSS and TAS were examined in light of the literature.

While no significant relationship was found between SSPT's academic achievement levels and the whole TAS and its emotionality sub-dimension, a negative, low-level and significant relationship was found in the worry subdimension. With reference to related literature, while studies pointing out a negative relationship between the test anxiety and academic achievement in terms of the whole TAS existed in literature [25,29,56,74,76,88,90,91,93], some studies claimed that there was no relationship between test anxiety and academic achievement [19,47,71]. In parallel with the findings of some studies, it was also found in this study that the emotionality sub-dimension of TAS had more effect on academic achievement than the worry sub-dimension did $[25,38,76,91]$. This can indicate that as the academic achievement level increases, the SSPTs' test anxiety level in the worry sub-dimension decreases. That is, a decrease in test anxiety can positively affect SSPT's academic achievements. Accordingly, it can be stated that activities to decrease the SSPT's test anxieties can contribute to their academic achievements because SSPTs with high test anxiety levels may have difficulty in concentrating on the exams.

Upon analysis of the relationship between SSPTs' academic achievement levels and their learning styles, it can be concluded that students with independent, cooperative and dependent learning styles increased their academic achievement levels at low level; that participant learning style increased SSPTs' academic achievements moderately; and that avoidant learning style affected SSPTs' academic achievements negatively and at low level. However, in the study by Hamidah and Sarina [46] in which GRLSS was used as the data collection tool, a significant relationship between cooperative learning style and academic achievement was found and it was stated that this learning style increased academic achievement. While many studies have stated that different learning styles positively affected students' academic achievements [e.g.,20,22,31,34,35,59,62,84], Busato, Prins, Elshout and Hamaker [9] concluded in their study that there was no significant relationship between academic achievement and learning styles.

The findings obtained with the analysis of GRLSS and TAS may indicate that having dependent, competitive and cooperative learning styles increases the points taken from the emotionality sub-dimension of TAS and that competitive learning style increases the worry subdimension of TAS, even if it does so at a low level. However, as stated in the previous section of the study, only the study by Hariri and Seadatee Shamir [47] examined the effect of learning styles on test anxiety while there were many studies examining the effects of many other variables on test anxiety. Kolb's Learning Style Inventory and Sarason Test Anxiety Questionnaire were used in their study and a negative relationship was found between learning styles and test anxiety. The difference between the two studies may result from the differences in sampling and scale. Therefore, it can be stated that further studies with different sampling and scales will contribute to the literature in terms of understanding the effects of learning styles on test anxiety better.

As for the relationship between gender and learning style, a statistically significant difference was observed in favor of males in avoidant learning style while the difference was in favor of females in dependent and cooperative learning styles. In the studies by Zelazek [92] and Hamidah and Sarina [46], it was concluded that gender did not affect learning styles. On the other hand, Zelazek [92] found that males and females had avoidant and cooperative learning styles respectively whereas Hamidah and Sarina [46] concluded that females achieved higher grades than males 
in cooperative, dependent, competitive and participant learning styles, which may result from the difference in sampling. Similarly, Çaycı and Ünal [23] also found in their study that male and female students have different learning styles, which is a finding that complies with the findings of this study. It can be stated that in the education process, these findings can be used in forming not only the learning style but also the teaching process.

When the relationship was examined between gender and test anxiety of SSPTs, it was seen that the test anxieties of female students were higher than those of the male ones in the whole TAS and the emotionality sub-dimension. While studies exist claiming that there is no significant difference between gender and test anxiety [29,71,74], there are also some studies whose findings reveal that the test anxiety levels of female students are higher than those of the male students $[18,39,52,89]$. Such differences in the results of various studies show the necessity to conduct similar studies in different cultures with different samplings for the subject to be understood better.

The results of the analysis showed that there was no significant relationship between SSPTs learning styles and class levels, which may indicate that the education in different class levels has no impact on learning styles. This finding complies with the finding of the study by Piji Küçük [74]. Finally, no significant difference was observed between the class levels of SSPTs and TAS in general or its sub-dimensions. This finding complies with the finding of the study by DordiNejad et al. [29] which claims that there is no significant relationship between test anxiety and class level.

\section{Recommendations}

In light of the findings of this study, recommendations for further studies are the following:

- SSPT consists of the study group of this study. Conducting a similar study with pre-service teachers from different departments could considerably contribute to literature in terms of understanding the relationship of field education specifically with learning styles and test anxiety.

- With reference to the opinion that an assessment of whether learning occurs must be through testing, the importance of tests in education has been gradually increasing and the success of students in exams has become a determinant not only for one lesson but also for certain life decisions [36]. Therefore, testing the effects of different variables with different samplings on test anxiety is thought to be useful for activities aiming to minimize students' test anxiety.

As learning styles focus on different dimensions of learning, it can be stated that dealing with the issue through various learning style scales could be useful in terms of testing the efficiency of learning styles on both test anxiety and academic success.

\section{REFERENCES}

[1] Albayrak Kaymak, D. (1987). Sinav kaygisı envanterinin Türkçe formunun olușturulması ve güvenirliği. [The development and reliability of the Turkish form of the test anxiety inventory.] Psikoloji Dergisi, 6(21), 55-62.

[2] Angrist, J. D., \& Lavy, V. (1999). Using Maimonides' rule to estimate the effect of class size on scholastic achievement. The Quarterly Journal of Economics, 114(2), 533-575.

[3] Așçı, M., Işlak, O., \& Güler, Ş. (2015). Yükseköğretim programlarının sınama durumlarında kullanılan ölçme araçlarının öğrencilerin sınav kaygıları üzerine etkileri Celal Bayar Üniversitesi eğitim fakültesi örneği. [The effects of evaluation instruments used for assessment and measurement at higher education on students' exam anxiety the example of the faculty of education at Celal Bayar University.] Celal Bayar Üniversitesi Sosyal Bilimler Dergisi, 13(4), 185-198.

[4] Ayranc1, E., \& Öge, E. (2011). Bir vakıf üniversitesindeki ögrencilerin sınav kaygısı hakkında araştırma. [Research on test anxiety of students in a private university.] Dumlupinar Üniversitesi Sosyal Bilimler Dergisi, 30, 87-102.

[5] Azhar, M., Nadeem, S., Naz, F., Perveen, F., \& Sameen, A. (2013). Impact of parental education and socio-economic status on academic achievements of university students. International Journal of Academic Research and Reflection, 1(3), 25-33.

[6] Barlow, D. H. (2002). Anxiety and its disorders: The Nature and treatment of anxiety and panic. New York: Guilford Press.

[7] Barrows, J., Dunn, S., \& Lloyd, C. A. (2013). Anxiety, selfefficacy, and college exam grades. Universal Journal of Educational Research, 1(3), 204-208.

[8] Burns, D. J. (2004). Anxiety at the time of the final exam: Relationships with expectations and performance. Journal of Education for Business, 119-124.

[9] Busato, V. V., Prins, F. J., Elshout, J. J., \& Hamaker, C. (2000). Intellectual Ability, learning style, personality, achievement motivation and academic success of psychology students in higher education. Personality and Individual Differences, 29(6), 1057-1068.

[10] Bushman, B. J., Vagg, P. R., \& Spielberger, C. D. (2005). Culture and gender factors in the structure of the test anxiety inventory: A Meta-analysis. In Charles D. Spielberger and Irwin G. Sarason (Ed.), Stress and Emotion: Anxiety, Anger and Curiosity, (pp.77-96), Volume 17, NY, USA: Routledge.

[11] Büyüköztürk, Ş. (2008). Sosyal bilimler için veri analizi el kitabl. [Data analysis handbook for social sciences.] (9th. Ed). Ankara, Turkey: Pegem Akademi.

[12] Caldas, S. J., \& Bankston, C. (1997). Effect of school population socioeconomic status on individual academic achievement. The Journal of Educational Research, 90(5), 269-277. 
[13] Cano, J. (1999). The relationship between learning style, academic major, and academic performance of college students. Journal of Agricultural Education, 40(1), 30-37.

[14] Cano, J., \& Garton, B. L. (1994). The relationship between agriculture pre-service teachers' learning styles and performance in a methods of teaching agriculture course. Journal of Agricultural Education, 35(2), 6-10.

[15] Cassady, J. C., \& Johnson, R. E. (2002). Cognitive test anxiety and academic performance. Contemporary Educational Psychology, 27, 270-295.

[16] Cassidy, S. (2012). Intellectual styles: Measurement and assessment. In L. Zang, R. J. Sternbergand S. Rayner (Ed.), Handbook of Intellectual Styles: Preferences in Cognition, Learning, and Thinking, (pp. 67-89), NY, USA: Springer Publishing.

[17] Cesur, M. O., \& Fer, S. (2009). What is validity and reliability study of learning style survey? Journal of Theory and Practice in Education, 5(2), 289-315.

[18] Chapell, M. S., Blanding, Z. B., Silverstein, M. E., Takahashi, M., Newman, B., Gubi, A., \& McCann, N. (2005). Test anxiety and academic performance in under grade and graduate students. Journal of Educational Psychology, 97(2), 268-274.

[19] Cheraghian, B., Fereidooni-Moghadam, M., Baraz-Pardejani, S., \& Bavarsad, N. (2008). Test anxiety and its relationship with academic performance among nursing students. Knowledge \& Health, 3(3-4), 25-29.

[20] Chowhan, S. (2013). Academic performance of engineering students: The role of abilities \& learning style. International Scholarly and Scientific Research \& Innovation, 7(1), 308314.

[21] Chun-Shih, C., \& Gamon, J. A. (2002). Relationships among learning strategies, patterns, styles and achievement in webbased courses. Journal of Agricultural Education, 43(4), 111 .

[22] Collinson, E. (2000). A Survey of elementary students' learning style preferences and academic success. Contemporary Education, 71(4), 42-46.

[23] Çaycı, B., \& Ünal, E. (2007). Sınıf öğretmeni adaylarının sahip oldukları öğrenme stillerinin çeşitli değişkenlere göre incelenmesi. [Investigation of the classroom teachers' learning styles in terms of several variables.] Bilim, Eğitim ve Düsünce Dergisi, 7(3), 1-16. Retrieved from http://www.universite-toplum.org/text.php3?id=328.elenk. Accessed 22April 2015.

[24] Deb, S., Strodl, E., \& Sun, J. (2014). Academic-related stress among private secondary school students in India. Asian Education and Development Studies, 3(2), 118-134.

[25] Deffenbacher, J. L., Deitz, S. R., \& Hazaleus, S. L. (1981). Effects of humor and test anxiety on performance, worry, and emotionality in naturally occurring exams. Cognitive Therapy and Research, 5(2), 225-228.

[26] Den Brok, P., Brekelmans, M., \& Wubbels, T. (2004). Interpersonal teacher behavior and student outcomes. School Effectiveness and School Improvement, 15(3-4), 407-442.

[27] Deveci, T. (2013). Adaptation of social interaction learning styles by freshman engineering students in communication courses. Yüksek Öğretim Dergisi, 3(3), 121-128.

[28] Diaz, D. P., \& Cartnal, R. B. (1999). Students' learning styles in two classes: online distance learning and equivalent oncampus. College Teaching, 47(4), 130-135.

[29] DordiNejad, F. G., Hakimi, H., Ashouri, M., Dehghani, M., Zeinali, Z., Daghighi, M. S., \& Bahrami, N. (2011). On the relationship between test anxiety and academic performance. Procedia Social and Behavioral Sciences, 15, 3774-3778.

[30] Dunn, R. (1984). Learning Style: State of the Science. Theory into Practice, 23(1), 10-19.

[31] Dunn, R. S., \& Dunn, K. J. (1979). Learning styles/teaching styles: should they...can they...be matched? Educational Leadership, 36(4), 238-244.

[32] Dunn, R., \& Griggs, S. (1998). Multiculturalism and learning style: Teaching and counseling adolescents. (2nd Ed.). Westport, USA: Praeger.

[33] Dunn, R., DeBello, T., Brennan, P., Krimsky, J., \& Murrain, P. (1981). Learning style research define differences differently. Educational Leadership, 38, 372-375.

[34] Dunn, R., Griggs, S. A., Olson, J., Beasley, M., \&Gorman, B. S. (1995). A Meta-analytic validation of the Dunn and Dunn model of learning style preferences. The Journal of Educational Research, 88, 353-362.

[35] Dunn, R., Honigsfeld, A., Doolan, L. S., Bostrom, L., Russo, K., Schiering, M. S., Suh, B., \& Tenedero, H. (2009). Impact of learning-style instructional strategies on students' achievement and attitudes: perceptions of educators in diverse institutions. The Clearing House: A Journal of Educational Strategies, Issues and Ideas, 82(3), 135-140.

[36] Elçin Boyacıoğlu, N., \& Küçük, L. (2011). Ergenlikte mantık dışı inançlar sınav kaygısını nasıl etkiliyor? [How do irrational beliefs affect test anxiety during adolescence?] Journal of Psychiatric Nursing, 2(1), 40-45.

[37] Eret, E., Gokmenoglu, T., \& Engin-Demir, C. (2013). A review of research on educational theories and approaches affecting student's achievement: 1990-2011. Elementary Education Online, 12(3), 687-700.

[38] Ergene, T. (2011). The Relationships Among Test Anxiety, Study Habits, Achievement, Motivation and Academic Performance Among Turkish High School Students. Education and Science, 36(160), 320-330.

[39] Everson, H. T. Millsap, R. E., \& Rodriguez, C. M. (1991). Isolating gender differences in test anxiety: A confirmatory factor analysis of the test anxiety inventory. Educational and Psychological Measurement, 51, 243-251.

[40] Felder, R. M., \& Spurlin. J. (2005). Applications, reliability and validity of the index of learning styles. International Journal of Engineering Education, 21(1), 103-112.

[41] Fortuin, J., van Geel, M., \& Vedder, P. (2016). Peers and academic achievement: A longitudinal study on selection and socialization effects of in-class friends. The Journal of Educational Research, 109(1), 1-6.

[42] Ganyaupfu, E. M. (2013). Teaching methods and students' academic performance. International Journal of Humanities and Social Science Invention, 2(9), 29-35.

[43] Geary, W. T., \& Sims, R. R. (1995). Adapting Faculty and Student Learning Styles: Implications for Accounting 
Education. In Ronald R. Sims and Serbrenia J. Sims (Ed.), The importance of learning styles: Understanding the implications for learning, course design, and education, (pp.111-127). Westport, USA: Greenwood Publishing.

[44] Gregorc, A. F. (1979). Learning/teaching styles: Potent forces behind them. Educational Leadership, 36(4), 234-236.

[45] Gülbahar, Y. (2005). Öğrenme stilleri ve teknoloji. [Learning styles and technology.] Education and Science, 30(138), 1017.

[46] Hamidah, J. S., \& Sarina, M. N. (2009). The social interaction learning styles of science and social science students. Asian Social Science, 5, 58-64.

[47] Hariri, S. A., \& Seadatee Shamir, A. (2014). Self-directing skills, metacognitive beliefs, learning styles and exam anxiety in state high school students. International Journal of Education and Applied Sciences, 1(7), 334-342.

[48] Hashmat, S., Hashmat, M., Amanullah, F., \& Aziz, S. (2008). Factors causing exam anxiety in medical students. Journal of Pakistan Medical Association, 58(4), 167-170.

[49] Hawk, T. F., \& Shah A. J. (2007). Using learning style instruments to enhance student learning. Decision Sciences Journal of Innovative Education, 5(1), 1-19.

[50] Heyneman, S. P. (2005). Student background and student achievement: What is the right question? American Journal of Education, 112(1), 1-9.

[51] Hickcox, L. K. (1995). Learning styles: A survey of adult learning style inventory models. In Ronald R. Sims and Serbrenia J. Sims (Eds.), The Importance of learning styles: Understanding the implications for learning, course design, and education (pp. 25-48). USA: Greenwood Publishing.

[52] Hong, E., \& Karstensson, L. (2002). Antecedents of state test anxiety. Journal of Contemporary Educational Psychology, 27(2), 348-367, 2002.

[53] Joy, S. \& Kolb, D. A. (2009). Are there cultural differences in learning style? International Journal of Intercultural Relations, 33, 69-85.

[54] Karasar, N. (2012). Bilimsel araştırma yöntemi. [Scientific research method.] (23th Ed.). Ankara, Turkey: Nobel Yayınc1lik.

[55] Kaya, M. F. (2015). Sosyal bilgiler öğretmenlerinin başarı algılarının belirlenmesine yönelik nitel bir çalıșma. [A qualitative research on determination of social studies teachers' perceptions of success.] Turkish Studies, 10, 563584.

[56] Khalaila, R. (2015). The relationship between academic selfconcept, intrinsic motivation, test anxiety, and academic achievement among nursing students: mediating and moderating effects. Nurse Education Today, 35, 432-438.

[57] Klein, J. (2001). Attention, scholastic achievement and timing of lessons. Scandinavian Journal of Educational Research, 45(3), 301-309.

[58] Kolb, A. Y., \& Kolb, D. A. (2005). Learning styles and learning spaces: enhancing experiential learning in higher education. Academy of Management Learning and Education, 4(2), 193-212.

[59] Kvan, T., \& Jia, Y. (2005). Students' learning styles and their correlation with performance in architectural design studio.
Design Studies, 26(1), 19-34.

[60] Lacour, M., \& Tissington, L. D. (2011). The effects of poverty on academic achievement. Educational Research and Reviews, 6(7), 522-527.

[61] Lufi, D., Okasha, S., \& Cohen, A. (2004). Test anxiety and its effect on the personality of students with learning disabilities. Learning Disability Quarterly, 27, 176-184.

[62] Lynch, T. G., Woelfl, N. N., Steele, D. J., \& Hanssen, C. S. (1998). Learning style influences student examination performance. The American Journal of Surgery, 176(1), 6266.

[63] Martin, A. (2002). Motivation and academic resilience: Developing a model for student enhancement. Australian Journal of Education, 46(1), 34-49.

[64] McDonald, S. A. (2001). The prevalence and effects of test anxiety in school children. Educational Psychology, 21(1), 89-101.

[65] Momanyi, J. M., Too, J., \& Simiyu, C. (2015). Effect of students' age on academic motivation and academic performance among high school students in Kenya. Asian Journal of Education and e-Learning, 3(5), 337-342.

[66] Monks, J., \& Schmidt, R. (2010). The impact of class size and number of students on outcomes in higher education. [Electronic version]. Retrieved from http://digitalcommons.il r.cornell.edu/workingpapers/114/.

[67] Mota, D., Reis, L. P., \& Carvalho, C. V. (2014). CrossArtefacts for the Purpose of Education. In Edited by Álvaro Rocha, Ana Maria Correia, Felix B. Tan and Karl. A Stroetmann (Ed.), New perspectives in information systems and technologies, Vol. 2- Advances in Intelligent Systems and Computing Series, (pp. 487-496). Vol. 276, London, UK: Springer.

[68] Moussa, N. M. (2014). The importance of learning styles in education. Institute for Learning Styles Journal, 1, 19-27.

[69] Mutlu, M. (2008). Eğitim fakültesi öğrencilerinin öğrenme stilleri. [Learning styles of education faculty students.] Kazım Karabekir Eğitim Fakültesi Dergisi, 17,1-21.

[70] NCSS "National Council for the Social Studies" (1994). National Curriculum Standards for Social Studies: Executive Summary. Retrieved from http://www.socialstudies.org/stan dards/execsummary.

[71] Ndirangu, G. W., Muola, J. M., Kithuka, M. R., \& Nassiuma, D. K. (2010). An investigation of the relationship between test anxiety and academic performance in secondary schools in Nyeri district, Kenya. Global Journal of Educational Research, 8(1/2), 1-7.

[72] Öner, N. (1990). Sinav kaygısı envanteri el kitabı. [Handbook of test anxiety inventory.] İstanbul, Turkey: Yöret Vakfi Yayını.

[73] Öner, N. (2006). Türkiye'de kullanılan psikolojik testlerden örnekler: Bir başvuru kaynağı. [Examples of psychological tests used in Turkey: An application reference.] (2nd Ed.). İstanbul: Boğaziçi Üniversitesi Yayınevi.

[74] Piji Küçük, D. (2010). Müzik öğretmeni adaylarının sınav kaygısı, benlik saygısı ve çalgı başarıları arasındaki ilișkinin incelenmesi. [Assessment of relation between test anxiety, 
self-esteem and success in instrument for candidates of music teacher.] Ahi Evran Üniversitesi Eğitim Fakültesi Dergisi, 11(3), 37-50.

[75] Pritchard, A. (2009). Ways of learning: Learning theories and learning styles in the classroom. (2nd Ed.). NY, USA: Routledge.

[76] Rana, R. A., \& Mahmood, N. (2010). The relationship between test anxiety and academic achievement. Bulletin of Education and Research, 32(2), 63-74.

[77] Richardson, M., Abraham, C., \& Bond, R. (2012). Psychological correlates of university students' academic performance: a systematic review and meta-analysis. Psychological Bulletin, 138(2), 353-387.

[78] Riechmann, S. W., \& Grasha, A. F. (1974). A rational approach to developing and assessing the construct validity of a student learning style scales instrument. The Journal of Psychology, 87, 213-223.

[79] Roney, S. D., \& Woods, D. R. (2003). Ideas to minimize exam anxiety. Journal of Engineering Education, 92(3), 249-256.

[80] Sarason, I. G. (1984). Stress, anxiety, and cognitive interference: Reactions to tests. Journal of Personality and Social Psychology, 46, 929-938.

[81] Sarıtaş, E., \& Süral, S. (2010). Grasha-Reichmann [Riechmann] öğrenme ve öğretme stili ölçeklerinin Türkçe uyarlama çalışması. [A study for the adaptation of the Grascha-Reichman [Riechmann] learning and teaching style scales.] E-Journal of New World Sciences Academy, 5(4), 2162-2177.

[82] Sims, R. R., \& Sims, S. J. (1995). Learning enhancement in higher education. In Ronald R. Sims and Serbrenia J. Sims (Ed.), The Importance of learning styles: Understanding the implications for learning, course design, and education, (pp. 1-24). London, UK: Greenwood Press.

[83] Sud, A. (2001). Test anxiety research in India: twentieth century in retrospect. Psychology Developing Societies, 13(1), 51-69.

[84] Tinajero, C., Lemos, S. M., Araújo, M., Ferraces, M. J., \& Páramo, M. F. (2012). Cognitive style and learning strategies as factors which affect academic achievement of Brazilian university students. Psicologia: Reflexão E Crítica, 25(1), $105-113$.

[85] Topses, G. (2000). Öğrenci davranışlarını etkileyen sosyal ve psikolojik faktörler ve sorunlar. [Social and psychological factors and problems affecting student behaviors.] In Prof. Dr. Leyla Küçükahmet (Ed.), Sinıf Yönetimi [Classroom Management] (pp. 1-26). Ankara, Turkey: Nobel Yayın Dağıtım.

[86] Trifoni, A., \& Shahini, M. (2011). How does exam anxiety affect the performance of university students? Mediterranea $n$ Center of Social and Educational Research, 2(2), 93-100.

[87] Von Der Embse, N. P., Schultz, B. K., \& Draughn, J. D. (2015). Readying students to test: The influence of fear and efficacy appeals on anxiety and test performance. School Psychology International, 36(6), 620-637.

[88] Von Der Embse, N., \& Hasson, R. (2012). Test anxiety and high-stakes test performance between school settings: implications for educators. Preventing School Failure: Alternative Education for Children and Youth, 56(3), 180187.

[89] Williams, J. E. (1996). Gender-related worry and emotional test anxiety for high-achieving students. Psychology in the Schools, 13, 159-162, 1996.

[90] Yıldırım, İ., Gençtanırım, D., Yalçın, İ., \& Baydan, Y. (2008). Academic achievement, perfectionism and social support as predictors of test anxiety. Hacettepe Üniversitesi Eğitim Fakültesi Dergisi, 34, 287-296.

[91] Zeidner, M. (1990). Does test anxiety bias scholastic aptitude test performance by gender and sociocultural group? Journal of Personality Assessment, 55, 145-160.

[92] Zelazek, J. R. (1986). Learning styles, gender, and life cycle stage: relationships with respect to graduate students. (Eric Document Reproduction Service. No. ED 276). Retrieved from http://Files.Eric.Ed.Gov/Fulltext/ED276371.Pdf. Acces sed 23 November 2015.

[93] Zhang, N., \& Henderson, C. N. R. (2014). Test anxiety and academic performance in chiropractic students. Journal of Chiropractic Education, 28(1), 2-8. 